DOI: http://dx.doi.org/10.4314/star.v4i2.29 ISSN: 2226-7522(Print) and 2305-3372 (Online) Science, Technology and Arts Research Journal Sci. Technol. Arts Res. J., April-June 2015, 4(2): 222-227 Journal Homepage: http://www.starjournal.org/

Original Research

\title{
Effects of Different Feeding Regimes on Leather Quality of Finished Blackhead Ogaden Sheep
}

\author{
Fasil Negussie*, Mengistu Urge, Yoseph Mekasha and Getachew Animut
}

\author{
School of Animal and Range Sciences, Haramaya University, Dire Dawa, Ethiopia
}

\begin{tabular}{|c|c|}
\hline Abstract & Article Information \\
\hline $\begin{array}{l}\text { The objective of this study was to determine the effects of different roughage to concentrate } \\
\text { ratios on chemical and physico-mechanical quality of leather of Blackhead Ogaden sheep. } \\
\text { Twenty four lambs were initially blocked into } 6 \text { blocks of four lambs each based on body weight } \\
\text { and randomly assigned to } 4 \text { dietary groups. During the growth phase, sheep consumed natural } \\
\text { grass hay ad libitum and a mixture of dried Acacia albida leaves with pods, and cactus pear } \\
\text { cladodes ( }(2: 1 \text { ratio, respectively) as a supplement at } 0,0.9,1.2 \text { and } 1.5 \% \text { of body weight in } \\
\text { group A, B, C and D, respectively. During the finishing phase, roughage composed of natural } \\
\text { grass hay and haricot bean haulms ( } 50: 50 \text { ratio) and concentrate mixture composed of wheat } \\
\text { bran }(69 \%) \text { and } 31 \% \text { of oil seed meal (noug seed meal and cotton seed meal in the ratio of } \\
1.1: 1) \text { were consumed at roughage to concentrate ratios of } 60: 40,50: 50,40: 60 \text {, and } 30: 70 \text { by } \\
\text { the groups, respectively. After completion of } 180 \text { days of stall feeding, all animals were } \\
\text { slaughtered for leather quality test studies. Except the moisture content at wet blue stage, which } \\
\text { was higher }(P<0.05) \text { for group A than group C, all the chemical quality test of leather were not } \\
\text { significantly }(P>0.05) \text { different among the groups. Physico-mechanical quality parameters of } \\
\text { leather such as thickness, tensile strength, percentage of elongation, tear load, tear resistance, } \\
\text { distension at burst, were significantly improved ( } P<0.05) \text { due to increased proportion of } \\
\text { concentrate, and were higher for group C. However, water absorption }(\mathrm{v} / \mathrm{m}) \text { was significantly } \\
\text { lower }(P<0.05) \text { for leather produced from group A. Shrinkage temperature and water absorption } \\
\text { at } 24 \text { hr }(\mathrm{v} / \mathrm{v}) \text { did not vary }(P>0.05) \text { due to treatment. It can be concluded that increasing levels } \\
\text { of concentrate in the diet improved production of leather that meet the acceptable range set by } \\
\text { Ethiopian leather industry in most of the test parameters. However, from most of the values of } \\
\text { the physico-mechanical quality parameters, group } C \text { is recommended as better feeding regime. } \\
\text { Copyright@2015 STAR Journal, Wollega University. All Rights Reserved. }\end{array}$ & $\begin{array}{l}\text { Received : 29-04-2015 } \\
\text { Revised : } 17-06-2015 \\
\text { Accepted : 18-06-2015 } \\
\text { Keywords: }\end{array}$ \\
\hline
\end{tabular}

\section{INTRODUCTION}

In Ethiopia, hides, skins and leather products are the second major export products and this sector accounted $18 \%$ of the total foreign exchange earnings (Arend, 2006). Ethiopian small ruminant skins especially sheep skins traditionally have good reputation for quality in the world leather market due to their fine grain and compact structure (Zeleke, 2009). Sheep and goats are among the major economically important livestock in Ethiopia (Adane and Girma, 2008). However, seasonal quantitative and qualitative fluctuations in feed supply are bottlenecks for enhanced productivity. Animals maintained on poor nutrition result in low rates of production, often defined by growth and reproduction (Alemu, 2008). Hides and skins derived from animals suffering from prolonged and bitter starvation are thin and friable, leather which are produced from such hides and skins are noted for their dryness and flabbiness (Teklay, 2010).

In Ethiopia, over the last 10 years, there are indications that the quality of raw material has deteriorated due to many factors. This has resulted in an ever increasing number of complaints about the quality of skins available to local tanners and the export market
(Zeleke, 2009) causing economic lose to the pastoralists/farmers and the country in general (MOARD, 2007). Among the widespread constraints, environmental factors (breed/type, sex/age, nutrition and climate) are the major factors that contribute to the deterioration of the quality of skin for leather production. Poor nutrition is one of the environmental factors that cause the skin to be thinner, have poorer substance producing leather which lacks elasticity and have a finer grain due to less fat deposition (Zeleke, 2009). Jacinto et al. (2004) also noted that the quality of sheep leather is influenced by the breeds and age of animals (intrinsic factors) or by nutrition and by the marks on the skin acquired during the lifetime of the animal (extrinsic factors). Due to this, improving the quality of the raw material is becoming a grown national concern. Therefore, the present experiment was conducted to assess the effect of various proportion of roughage to concentrate on the chemical and physicomechanical quality of leather produced from Blackhead Ogaden sheep when compared to Ethiopian leather quality standards. 


\section{MATERIALS AND METHODS}

Description of the Study Area

The experiment was conducted at Haramaya University Goat Farm $\left(9.0^{\circ} \mathrm{N}\right.$ and $\left.42.0^{\circ} \mathrm{E}\right)$, located at 515 $\mathrm{km}$ east of Addis Ababa, Ethiopia. The site is situated at an altitude of 1950 m.a.s.I., and has an average temperature of $16^{\circ} \mathrm{C}$ and means annual rainfall of $790 \mathrm{~mm}$ (Mishra et al., 2004).

\section{Experimental Animals and Management}

A total of 24 yearling intact Blackhead Ogaden lambs with a mean initial body weight of $17.3 \pm 0.52 \mathrm{~kg}$ were used for the study. Animals were purchased from Jigjiga open local markets in Somali National Regional State. As estimated from dentition, the age of the animals at slaughter was about 14 to 16 months. Experimental animals were quarantined for 3 weeks after arrival at Haramaya University. During the quarantine period, the experimental animals were vaccinated against common infectious diseases in the area (pasteurelosis and anthrax), de-wormed against internal parasites by albendazol de-wormer, and sprayed with acaricides (Vetacidin 20\%) against external parasites. Animals were housed in individual pens with a dimension of $70 \times 120 \mathrm{~cm}$ equipped with a feeding trough and watering bucket. Animals were adapted to experimental procedures and feeds for 14 days before the commencement of stall feeding. All the management procedures of experimental animals were carried out according to the Institution and international guidelines for animal welfare.

\section{Experimental Feeds Preparation and Feeding}

Natural grass hay as a basal diet and dried Acacia albida leaves and pods, and cactus pear (Opuntia ficusindica L.) were mixed at the ratio of $2: 1$ and used as a supplement during the first three months (growth phase). Fresh leaves of the Acacia were harvested from available trees regardless of the plants age, trimmed with its pods, spread thinly on plastic sheet under shade and turned regularly to ensure uniform drying for safe storage. Likewise, the cactus cladodes were hand chopped into pieces or strips to an approximate size of $5 \mathrm{~mm}$ for ease of feeding and drying and spread thinly on plastic sheet under shade and dried. During the second three months (finishing phase), the same natural pasture hay used during growth phase and haricot bean haulms in a ratio of 50:50 (Dejen, 2010; Emebet, 2008) were used as a basal diet. The roughages were separately chopped by hand tool to a length of approximately $5 \mathrm{~mm}$ for simplicity of mixing and to reduce selection by animals. The supplement feed in the finishing phase comprise $69 \%$ wheat bran and $31 \%$ oil seed meals (noug and cotton meals in 1.1:1 ratio). The roughage and the concentrate feeds were offered in a separate feeder at 08:00 AM and 05:00 PM in equal meals. Feed was offered on ad libitum basis and feed offer was adjusted to $120 \%$ based on the previous four days intake. The proportion of roughage to concentrate was determined from animals' ad libitum intake and calculated on dry matter basis. Clean tap water and salt blocks were available all the time.

\section{Experimental Design and Treatments}

The experiment design employed was a completely randomized block design. The animals were blocked into six blocks of four animals each based on their initial body weight. The treatments were based on graded levels of Acacia albida and cactus mixture (ACM) and different proportions of roughage (R) to concentrate (C) supplementations during the growth and finishing phases, respectively. Accordingly, the treatments were designated as group $A(0 \% A C M$ in growth phase and 60R:40C in finishing phase $), B(0.9 \%$ body weight $A C M$ and 50R:50C), C (1.2\% body weight ACM and 40R:60C), and $\mathrm{D}(1.5 \%$ body weight $\mathrm{ACM}$ and $30 \mathrm{R}: 70 \mathrm{C})$. Skin Handling and Processing for Chemical and
Physico-Mechanical Leather Quality

After six months stall feeding trail, all animals were slaughtered in the abattoir of the university and skin was carefully flayed by hand. The skin could not be delivered to the tannery immediately after slaughtering because of the far distance of the tannery from the university. Hence, wet salting method was used to preserve and prevent putrefaction and quality deterioration till it was transported to the Ethiopian Leather Industry Development Institute $(L I D I)$. Wet salting was carried out in accordance with Ethiopian standard authority. Before spreading the salt, excess flesh/meat and fat were gently removed and the skins were washed with clean tap water according to the Ethiopian standard authority code ESA code B.J6. 003 (1990). The amount of salt used was $50 \%$ of the mass of the fresh skin. The salt was gently and evenly spread on the flesh side of the skin. The skin was carefully folded and kept at a slant position in order to allow the oozing of moisture from the skin. The skins were under these conditions for seven days in a well- ventilated shed. The wet salted skin was taken to $L I D I$ for quality assessment of a conventional garment leather manufacturing process according to the standards of the institute. The major steps involved in skin processing were: soaking, liming, de-liming, bating, degreasing, pickling, tanning, neutralization, re- tanning, dying, drying, and finishing. The leather quality of the sheep skin was then assessed for chemical and physico- mechanical characteristics. The finished sheep garment leathers were taken to the LIDI physical and chemical laboratory and conditioned at $20 \pm 2$ ${ }^{\circ} \mathrm{C}$ under $65 \pm 5 \%$ relative humidity for $48 \mathrm{~h}$ prior to physico- mechanical testing according to the guidelines developed by LIDI. Triplicate samples were taken from each skin parallel (horizontal) or perpendicular (vertical) to the backbone. The testing and sampling sites were determined in accordance to ISO-2418 (2002).

\section{Chemical Quality Test of Leather \\ Fat Content}

The fat content of the moisture free samples were determined using the standard Soxhlet extraction method (IUC-4 1998) with fat extracted using the solvent dichloromethane. The process was allowed until the fat is completely extracted, at least for 5 hours.

\section{Chrome-oxide Content}

The amount of chrome present was determined and expressed as chromic-oxide. The chromic oxide content $\left(\mathrm{Cr}_{2} \mathrm{O}_{3}\right)$ of the leather was determined from the leather ash by oxidizing the leather ash followed by iodometric titration of hexavalent chromium ions (IUC-8, 1998).

\section{Physico-mechanical Quality of Leather \\ Tensile Strength and Percentage Elongation}

These were determined using the test methods of ISO3376 (2002). Sampling methods and sampling location were taken according to ISO-2418 (2005) and ISO-2418 (2002), respectively. 


\section{Tear Load}

Average tear load/arithmetic mean and tear resistance was determined using test methods of International Organization for Standardization (ISO-3376 2002) and ISO-3376 (2000), respectively. Samples were conditioned according to ISO-2419 (2002).

\section{Distension, Strength of Grain and Thickness of Lamb Skin}

Distension and strength of grain were determined by the ball burst test using a lastometer with methods described by International Organization for Standardization (ISO-3379, 2005). Thickness of lamb skins were measured using a digital leather thickness gauge.

\section{Shrinkage Temperature and Water Absorption}

Samples for shrinkage temperature were taken from individual skin and pooled per treatment for laboratory analysis. Water absorption measures the ability of the leather to absorb water within 24 hours after immersing in a simple glass apparatus called kubelka. Shrinkage temperature of leather was determined using test method of ISO-3380 (2002).

\section{Chemical Analysis of Feeds}

Feed samples were analyzed for dry matter (DM), ash organic matter (OM) and nitrogen according to procedures of AOAC (1990). Crude protein (CP) was estimated as $N$ $x$ 6.25. Neutral detergent fiber (NDF), acid detergent fiber (ADF) and acid detergent lignin (ADL) were analyzed according to Van Soest and Robertson (1985). The nutrient composition of feed ingredients used during the experiment is given in Table 1.

Table 1: Dry mater (\%) and nutrient (\% dry matter) concentration of feedstuffs

\begin{tabular}{cccccccc}
\hline Feeds & DM & OM & CP & NDF & ADF & ADL & Ash \\
\hline Hay & 90.7 & 90.7 & 7.8 & 67.6 & 33.2 & 21.5 & 9.3 \\
Haricot bean haulm & 91.3 & 90.1 & 6.7 & 62.1 & 38.9 & 7.0 & 9.9 \\
Acacia albida & 91.2 & 89.8 & 12.0 & 52.5 & 32.0 & 9.80 & 10.2 \\
Cactus cladodes & 90.3 & 82.0 & 5.99 & 23.3 & 15.0 & 2.40 & 18.0 \\
Wheat bran & 89.2 & 85.9 & 17.7 & 39.5 & 11.6 & 2.1 & 14.1 \\
Cottonseed meal & 91.8 & 80.8 & 28.0 & 34.9 & 30.0 & 7.7 & 19.1 \\
Noug seed meal & 91.0 & 89.2 & 40.0 & 41.9 & 15.2 & 8.3 & 10.8 \\
\hline \multicolumn{2}{c}{ ADF: acid detergent fiber, ADL: acid detergent lignin, CP: crude protein, }
\end{tabular}

DM: dry matter, NDF: neutral detergent fiber, OM: organic matter

\section{Statistical Analysis}

Data were analyzed using the general linear model procedure of SAS (2008). Mean differences were tested using Tukey honest significant differences test. The model for data analysis was: $Y_{i j}=\mu+T_{i}+B_{i}+E_{i j}$, Where $Y_{i j}=$ response variable; $\mu=$ the overall mean; $T_{i}$ the treatment effect; I = the block effect; Eij = the random error.

\section{RESULTS}

\section{Chemical Quality of Leather}

Moisture, Fat and Chrome-oxide Contents of Leather

The mean values of chemical tests of leather are presented in Table 2. Moisture content at crust, chrome oxide $\left(\mathrm{Cr}_{2} \mathrm{O}_{3}\right)$ and fat content did not show significant statistical differences $(P>0.05)$ among the diet groups. However, moisture content at wet blue was significantly higher $(P<0.05)$ for leather produced from lambs in groups $A$ than $C$, but was similar $(P>0.05)$ among group $A, B$, and $\mathrm{D}$, and $\mathrm{B}, \mathrm{C}$ and $\mathrm{D}$.

\section{Physico-mechanical Tests of Leather}

In the present study, except for shrinkage temperature and water absorption at $24 \mathrm{hrs}$, all the physicomechanicalquality properties of the leather were improved $(P<0.05)$ due to the feeding regimes (Table 3$)$.

Tensile Strength, Percentage of Elongation and Thickness

Levels of supplementation significantly increased $(P<0.05)$ tensile strength in group $\mathrm{C}$ as compared to group $A$, whereas values for group $B$ and group $D$ were similar $(P>0.05)$ with Group C. Similar to tensile strength, the feeding regimes improved percentage of elongation in group $C$ as compared to group $A$, whereas the value for group B was similar to group $\mathrm{C}$. Treatment had also positive $(P<0.05)$ effect on the thickness of lamb skins. The levels of concentrate improved the thickness of the leather in the order of Group $C>B>A>D$. However percentage of elongation was slightly higher for group $B$ and group $\mathrm{C}$.

Table 2: Effects of feeding regime on leather chemical tests of finished Blackhead Ogaden sheep

\begin{tabular}{lcccccc}
\hline \multicolumn{1}{c}{$\begin{array}{c}\text { Chemical tests } \\
\text { (\%) }\end{array}$} & \multicolumn{5}{c}{ Dietary treatments * } & \multirow{2}{*}{ SE } \\
\cline { 2 - 6 } & Group A & Group B & Group C & Group D & SEM \\
\hline Moisture at wet blue & $74.4^{\mathrm{a}}$ & $71.9^{\mathrm{ab}}$ & $69.4^{\mathrm{b}}$ & $73.9^{\mathrm{ab}}$ & $*$ & 5.29 \\
Moisture at crust & 10.1 & 10.1 & 9.8 & 9.6 & $\mathrm{~ns}$ & 0.50 \\
$\mathrm{Cr}_{2} \mathrm{O}_{3}$ & 4.3 & 3.9 & 3.5 & 3.9 & $\mathrm{~ns}$ & 0.76 \\
$\mathrm{Fat}$ & 13.2 & 13.9 & 15.1 & 14.0 & ns & 1.88 \\
\hline
\end{tabular}

${ }^{\text {ab }}$ Means with different letters in the same row significantly different; $\mathrm{Cr}_{2} \mathrm{O}_{3}=$ Chromic oxide; ${ }^{*} \mathrm{~A}=$ Hay ad libitum-no supplement during growth phase and 60:40 roughage $(R)$ to concentrate $(C)$ ratio consumed ad libitum during finishing phase; $B=$ supplemented with Acacia albida and Cactus pear cladodes mixture(ACM) at $0.9 \%$ body weight ( 2 to 1 ratio, respectively) and $50 \mathrm{R}: 50 \mathrm{C} ; \mathrm{C}=1.2 \%$ body weight $\mathrm{ACM}$ and 40R:60C; $\mathrm{D}=1.5 \%$ body weight $\mathrm{ACM}$ and 30R:70C.SL= significant level; $\mathrm{ns}=$ non significant; ${ }^{*}=P<0.05 ;{ }^{* *}=P<0.01$ 
Table 3: Effects of feeding regime on leather physical tests of finished Blackhead

\begin{tabular}{|c|c|c|c|c|c|c|}
\hline \multirow[b]{2}{*}{ Physical test } & \multicolumn{4}{|c|}{ Dietary treatments * } & \multirow[b]{2}{*}{ SL } & \multirow[b]{2}{*}{ SEM } \\
\hline & Group A & Group B & Group C & Group D & & \\
\hline Shrinkage temperature $\left({ }^{\circ} \mathrm{C}\right)$ & 99.6 & 100.0 & 99.5 & 100.0 & ns & 0.07 \\
\hline Thickness (mm) & $0.8^{\mathrm{C}}$ & $1.1^{\mathrm{ab}}$ & $1.3^{\mathrm{a}}$ & $0.9^{\mathrm{b}}$ & ** & 0.47 \\
\hline Tensile strength $\left(\mathrm{N} / \mathrm{mm}^{2}\right)$ & $26.7^{\mathrm{b}}$ & $30.0^{\mathrm{a}}$ & $30.4^{a}$ & $27.6^{\mathrm{a}}$ & * & 3.75 \\
\hline$\%$ Elongation & $77.2^{\mathrm{b}}$ & $86.1^{\mathrm{a}}$ & $86.2^{\mathrm{a}}$ & $77.0^{\mathrm{b}}$ & * & 9.27 \\
\hline Tear load mean force $(\mathrm{N})$ & $47.7^{\mathrm{b}}$ & $53.9^{a}$ & $55.0^{\mathrm{a}}$ & $43.8^{c}$ & * & 11.2 \\
\hline Tear resistance $(\mathrm{N} / \mathrm{mm})$ & $50.5^{\mathrm{a}}$ & $52.2^{\mathrm{a}}$ & $54.9^{\mathrm{a}}$ & $47.9^{\mathrm{b}}$ & * & 6.95 \\
\hline Distension at burst (mm) & $11.7^{\mathrm{b}}$ & $11.9^{\mathrm{b}}$ & $12.7^{\mathrm{a}}$ & $12.1^{\mathrm{ab}}$ & * & 0.95 \\
\hline PRB & $40.5^{\mathrm{b}}$ & $44.6^{\mathrm{ab}}$ & $48.9^{a}$ & $42.4^{\mathrm{b}}$ & * & 8.46 \\
\hline PPB & $55.0^{\mathrm{b}}$ & $63.3^{\mathrm{a}}$ & $58.9^{a}$ & $45.1^{\mathrm{c}}$ & ** & 18.3 \\
\hline Water absorption (v/v) & $165.0^{\mathrm{b}}$ & $182.0^{\mathrm{a}}$ & $204.0^{a}$ & $203.0^{\mathrm{a}}$ & * & 39.8 \\
\hline Water absorption $(\mathrm{v} / \mathrm{m})$ & 119.0 & 121.0 & 125.0 & 125.0 & ns & 6.22 \\
\hline
\end{tabular}

${ }^{a b c}$ Means with different letters in the same row significantly diffeent; PRB: parallel to the back bone, PPB: perpendicular to the back bone, ${ }^{*} A=$ Hay ad libitum-no supplement during growth phase and 60:40 roughage $(R)$ to concentrate $(C)$ ratio consumed ad libitum during finishing phase; $B=$ supplemented with $A$ cacia albida and Cactus pear cladodes mixture(ACM) at $0.9 \%$ body weight ( 2 to 1 ratio, respectively) and 50R:50C; $C=1.2 \%$ body weight $A C M$ and $40 \mathrm{R}: 60 \mathrm{C} ; \mathrm{D}=1.5 \%$ body weight $\mathrm{ACM}$ and $30 \mathrm{R}: 70 \mathrm{C}$ SL= significant level; ns $=$ non significant; ${ }^{*}=P<0.05 ;{ }^{* *}=P<0.01$

\section{Tear Load and Tear Resistance}

Treatment had positive $(P<0.05)$ effect both on tear load and tear strength. Skin of lambs in group $C$ required higher $(P<0.05)$ mean force $(\mathrm{N})$ to tear as compared to group $A$ and group $D$, but was similar between group $B$ and group $C$. Tear strength $\left(\mathrm{N} / \mathrm{mm}^{2}\right)$ was also higher $(P<0.05)$ for group $C$ as compared to group $D$, but was similar $(P>0.05)$ between groups $\mathrm{A}, \mathrm{B}$, and $\mathrm{C}$. Distension at burst of leather tells the performance of the leather to burst when multidirectional force is applied. Distension at burst increased with increased proportion of concentrate and was in the order of $\mathrm{A}=\mathrm{B}<\mathrm{C}=\mathrm{D}(P<0.05)$. Mean force requirement was significantly $(P<0.05)$ changed both levels of concentrate and sampling directions. Higher Ogaden sheep proportion of concentrate in the diet significantly $(P<0.05)$ increased the mean force requirements in both sampling direction, but the requirement of mean force was higher $(\mathrm{P}<0.05)$ for vertically sampled skin as compared to samples taken horizontally.

\section{Shrinkage Temperature and Water Absorption}

No significant $(P>0.05)$ difference was observed for water absorption $(\mathrm{v} / \mathrm{v})$ among treatment groups, whereas, water absorption $(\mathrm{v} / \mathrm{m})$ was significantly $(P<0.05)$ higher for group $C$ as compared to Group $A$, but was similar $(P>0.05)$ among group $\mathrm{B}, \mathrm{C}$, and $\mathrm{D}$. In general, increasing levels of concentrate improved water absorption capacity of leather and hence improved the degree of flexibility of lamb's leather.

\section{DISCUSSION}

\section{Chemical Quality of Leather}

Fat, Chrome-Oxide and Moisture Contents of Leather

Sheep skin is expected to contains $30-40 \%$ natural fat and it affects the extent to which the leather accept fat liquor substances with respect to the raw weight (Cassano et al., 2001) and degreasing operation is carried out to eliminate the excess fat substances. If natural fat is not sufficiently removed, it prevents the hydrophilic activities of chemicals (liquoring agents) and, therefore, some undesirable quality problems such as hardness to touch, loss of some physical strength, dyeing imperfection, and bad smells occurs in the finished product (Narayan, 2013). In the present study, the fat content in all treatment groups were above the minimum standard levels (4-10\%) for the upper shoe leather. Among the treatments, leather produced from lambs in group $\mathrm{C}$ had better fat liquor substances accepting ability than other treatment groups. Implying that it prevents the leather fibers from putrefaction, make the fibers to stick together, and improve their physical and mechanical capabilities (Virginija et al., 2012). The value of the fat content recorded in the present study was higher than that reported by Gerhard (1996) but lower than reported by Seid et al. (2012). Another important chemical quality parameters of skin is the chrome oxide content, which determines the resistance of the leather to decomposition. The average chromic oxide content of leather in the present study is $3.8 \%$ which is above the minimum requirement for garment leather (BASF, 1984) and $2.5 \%$ for shoe upper leather (ES-1188 2005). Absence of significant differences among the different diet groups for chromic oxide content was in agreement with Tsegay et al. (2012) for indigenous and cross bred sheep and Seid et al. (2012) for goats in Ethiopia raised under different levels of supplementation. In contrast to these findings, Stosic (1994) noted that leather made from skins of nutritionally restricted fed groups contain high level of chrome than adequately fed groups. The moisture content is an important characteristic and its determination is often classified as a chemical test. Nothing affects the ease with which a leather cracks on bending as the amount of moisture contained in the leather. A very small difference in the amount of moisture may produce a very remarkable effect (Blockey, 1919). Gerhard (1996) also indicated that extremely dried leather is susceptible to embrittlement and crankiness of the grain and excessive content of moisture may also cause formation of mould and increasing flabbiness. The moisture content at crust level recorded in this study was slightly lower than the minimum standard (12\%) of the Ethiopian Quality standards Authority (ES- 1188 2005) and the amount reported for semi-tanned indigenous goat skin (Mussa and Gasmelseed, 2013). This could be attributed to the crankiness of the grain and hence reduce the quality of the leather (Gerhard, 1996). The values for leather moisture at wet blue stage in all treatment groups were above the minimum (60\%) of Ethiopian Quality standards Authority (ES-1188 2005). The low moisture content in group $C$ could be attributed to over dosage of reactive chemical (fat liquoring substances) and this affect the running wet end operation of the leather (Leather International, 2007). 
Fasil Negussie et al.,

Physico-Mechanical Tests of Leather

Tensile Strength, Percentage of Elongation and Thickness

A good tensile strength value is desired in all leather types and this characteristic is an important indicator of leather quality (Venkatachalam, 1962). In this study, the maximum tensile strength value was $30.43 \mathrm{~N} / \mathrm{mm}^{2}$, which was greater than reported by Oliveira et al. (2007) for the native sheep (Santa Ines), Altan et al. (2010) for pickled goat skin and Tsegay et al. (2012) for Blackhead and Hararghe highland and their crosses with Dorper sheep, and lower than reported by Seid et al. (2012) for Arsi-bale goats and Onu et al. (2011) for indigenous goat skin under different feeding management. The elongation ability at break of leather provides information about the fullness property. Lower elongation at break value refers to a less elastic leather character. Less elastic leather cannot withstand the applied force and is not liked by leather processing industry. The maximum value for percentage of elongation was $86.3 \%$, which was greater than reported by Seid et al. (2012) and Altan et al. (2010) but lower than reported by Tsegay et al. (2012). The result of the present study indicated that, increasing level of supplement improved the thickness of leather and higher value of leather thickness was attributed to higher strength and percentage of elongation. Concomitant with the current study, Tsegay et al. (2012) and Seid et al. (2012) reported greater thickness for lamb and goat skins with higher levels of concentrate than lower level. However, Jacinto et al. (2004) and Oliveira et al. (2007) noted poor correlation between thickness of leather and tensile strength and percentage of elongation. In general, all combinations of treatments produced leather that fit to the quality standard set by Baden Aniline and SODA Factory (BASF, 1984). However, percentage of elongation was slightly higher for group $B$ and group $C$ indicating that leathers from these groups are being stronger and could be extended more before the upper grain layers cracks. The minimum tensile strength for quality leather is 19.6 $\mathrm{N} / \mathrm{mm}^{2}$ and the acceptable range for percentage of elongation is $40-80 \%$ in which the values of the present study fall.

\section{Tear Load and Tear Resistance}

Another group of strength parameters manifested in finished leathers during usage are tear load resistance (Altan et al., 2010). Tear strength was improved due to the increased level of supplement in the diets of animals. This is in line to (Passman and Summer, 1983) who reported that the leathers produced from better-fed wethers were more resistance to tearing, with a stronger and more extensible grain layer than the leathers produced from the poorer-fed wethers. Distension at burst of leather tells the performance of the leather to burst when multidirectional force is applied. A higher elasticity characteristic of the leather in vertical direction is more suitable in shoemaking. The result of the present study is in accordance with Oliveira et al.(2007) and Jacinto et al. (2011) who reported that vertically sampled leathers had significantly $(P<0.05)$ higher values for both strength and load compared to horizontally sampled leathers. However, Tsegay et al. (2012) found that horizontal sampling direction had numerically better tensile strength than vertical sampling direction to the back bone, which could be an attribute of the arrangement of the leather fiber when horizontal sampling direction was used. Shrinkage temperature of leather may differ depending on the type and amount of tanning and re-tanning agents used in
Sci. Technol. Arts Res. J., April-June 2015, 4(2): 222-227

processing and these are accepted as signifiers of the stabilization of collagen fibers (Behzat et al., 2004). The average value of shrinkage temperature obtained in this study was above $99{ }^{\circ} \mathrm{C}$ for all leather samples, which was above the minimum requirement $\left(90^{\circ} \mathrm{C}\right)$ of the Ethiopian Quality standard Authority for chrome tanned leather (ISO- 3380 2005). This indicates the leathering ability of the raw material. Investigation on water absorption capacity of leather is an important parameter in determining the quality of tanned leather (Onu et al., 2011). This parameter predicts behavior of the material in moist condition and it is used to estimate the wearing properties and in material selection (Virginija et al., 2004).

\section{CONCLUSIONS}

The present study indicated that regardless of the feeding regime, all lambs produced leathers that fulfilled most of the chemical and physico-mechanical quality parameters required by the leather industry in Ethiopia. However, supplementing with foliage at $1.2 \%$ body weight during the growth phase and 40:60 roughage to concentrate ration during finishing phase tended to favor most of the physical quality parameters of leather produced from Blackhead Ogaden sheep under tropical environmental management condition.

\section{Conflict of Interest}

All authors declared no conflict of interest.

\section{REFERENCES}

Adane, H., Girma, A. (2008). Economic significance of sheep and goats, In: Alemu, Y., Merkel, R.C. (Eds.) Sheep and goat production handbook. Addis Ababa, Ethiopia, p. 1-5.

Alemu, Y. (2008). Nutrition and feeding of sheep and goats, In: Alemu Y., Merkel R.C. (Eds.) Sheep and goat production handbook. Addis Ababa, Ethiopia, pp 103-159.

Altan, N., Ahmet, A., Gurbuz G., Burga, O. (2010). Study on Usability of Collagen Hydrolysate along with OxazoLIDIne in Leather Processing. http://www. tekstivekonfeksiyon.com. Accessed 15 April 2014.

AOAC (1990). Official Methods of Analysis of the Association of Official Analytical Chemists, $5^{\text {th }}$ ed. (AOAC: Arlington, Virginia).

Arend, J.N. (2006). Quick scan of the livestock and meat sector in Ethiopia. http//www.edepot.wur.nl/22877.htm. com. Accessed 1 December 2014.

BASF (1984). Vademecum para el tecnico en curticion. $2^{\text {nd }}$ ed. (BASF, Ludwigshafen, Germany).

Behzat, O., Bahri, B., Ozcan, S., Ahmet, A., Gokhan, Z. (2004). Some physical and chemical properties of Ostrich skins and leathers. Indian Journal of Chemical Technology 1: 654-658.

Blockey, J.R. (1919). Application of Oils and Greases to Leather. In: Shoe and Leather Reporter, Essex street, Boston, USA.

Cassano, A., Molinari, A., Romno, M., Drioli, E. (2001). Treatment of aqueous effluent of leather industry by membrane process. Journal of Membrane Science 118, 111-126.

Dejen, A. (2010). The effect of feeding different proportion of Maize stover and Haricot bean Phaseolus Vulgaris) haulms supplemented with mixture of concentrate diets on the performance of Hararghe highland goats. MSc thesis, Haramaya University, Ethiopia.

Emebet, L. (2008). Supplementation of Blackhead Ogaden sheep fed haricot bean (Phaseolus vulgaris) haulms with 
Fasil Negussie et al.,

mixtures of wheat bran and brewers dried grain: effects on feed utilization, live weight gain and carcass parameters. MSc thesis, Haramaya University, Ethiopia.

Gerhard, J. (1996). Possible defects of leather production: definitions causes, consequences, remedies and types of leather http://www.trove.nla.gov.av/version/27023944. Accessed 29 April 2014.

International Organization for Standardization (2000). Test methods of tear strength, ISO 3376. Leather and Leather Products Technology, Addis Ababa, Ethiopia.

International Organization for Standardization (2002). Sampling for physico- mechanical test, 'ISO 2418. Leather and Leather Products Technology, Addis Ababa, Ethiopia.

International Organization for Standardization (2002).Test methods of tear load, 'ISO 3376. Leather and Leather Products Technology, Addis Ababa, Ethiopia.

International Organization for Standardization (2002). Sampling methods for tear load and tear resistance, ISO 2419. Leather and Leather Products Technology, Addis Ababa, Ethiopia.

International Organization for Standardization (2002). Test methods of shrinkage temperature, 'ISO 3380. Leather and Leather Products Technology, Addis Ababa, Ethiopia.

International Organization for Standardization (2002).Test methods of tensile strength and percentage elongation, ISO 3376. Leather and Leather Products Technology, Addis Ababa, Ethiopia.

International Organization for Standardization (2002). Sampling methods and sampling location for elongation percentage, ISO 2418. Leather and Leather Products Technology, Addis Ababa, Ethiopia.

International Organization for Standardization (2005). Sampling methods and sampling location for tensile strength, ISO 2418. Leather and Leather Products Technology, Addis Ababa, Ethiopia.

International Organization for Standardization (2005). Test methods of distension and strength of grain, ISO 3379. Leather and Leather Products Technology, Addis Ababa, Ethiopia.

Jacinto, M., Junior, F., Martins, C., Pinto, G., Reis, A., Oliveira, A. (2011). Comparable evaluation of leather water proofing behavior upon hide quality. Influence of retanning and fat liquoring agents on leather structure and properties. Revista Brasileira de Zootecnia 8: 1830-1836.

Jacinto, M., Da Silva, S., Costa, R. (2004). Anatomic and structural characteristics of wool and non-wool sheep (Ovis aries L.) in regard to the physico-mechanical aspects of the leather. Brazilian Journal of Animal Science 4: 1001-1008.

Leather International (2007). Measuring the moisture content of wet-blue leather http://www.leathermag.com. Accessed 27April 2014.

Mishra, B.B., Heluf, G.K., Kibebew, K., Mohammed, A., Biruk, E. (2004). Soil and land resource inventory at the Alemaya University research farm with reference to land evaluation for sustainable agricultural management and production. In: Specific features and management options of soil and land resources of eastern Ethiopian highlands of sustainable agricultural production. Soil Sci. bulletin No 1. Synthesis of working papers, Alemaya University, Ethiopia.

MORAD (Ministry of Agriculture and Rural Development) (2007). Livestock Development Master Plan Study. Volume K: Hides and Skins Production and Marketing Diagnostic Study. Addis Ababa, Ethiopia.
Sci. Technol. Arts Res. J., April-June 2015, 4(2): 222-227

Mussa, A.E., and Gasmelseed, G.A. (2013). Semi-chrome upper leather from rural goats vegetable tanned crust. Journal Applied and Industrial Science 1: 43-48.

Narayan, K.S. (2013). Green Approach to Leather Technology. MSC thesis, University of Applied Science, Centria.

Official methods of analysis (1998). Test method of substances extractable by Dichloro methane. Society of Leather and Chemists, IUC -4. Leather and Leather products Institute, Addis Ababa, Ethiopia.

Official methods of analysis (1998). Test method of chromic oxide, Society of Leather, Society of Leather and Chemists, IUC-8. Leather and Leather products Institute, Addis Ababa, Ethiopia.

Oliveira, R., Costa, R., Sousa, W., Medeiros, A. (2007). Influence of genotype on physico-mechanical characteristics of goat and sheep leather. Small Ruminant Research 73: 181-185.

Ono, S., Ika, A., Kartika, M., Shiva, A. (2011). Accelerated Chamois Leather Tanning Process Using Hydrogen Peroxide as an Oxidizing Agent, In: International Seminar on Chemical Engineering, Darmaga, Indonesia.

Passman, A., Summer, R. (1983). Effects of breeds and level of feeding on leather production of 18 month old wethers. New Zealand Journal of Experimental Agriculture 11: 4752.

Quality and Standards Authority of Ethiopia (2005). Ethiopian standard for chrome crust leather specification, ES-1188. Leather and Leather products Technology Institute, Addis Ababa, Ethiopia.

SAS (SAS Guide to Personal Computer) (2008) Version 9.1.3. Statistical Analysis System institute, Cary.

Seid, M., Mengist, U., Getachew, A., Kassahun, A., Girma, A., Arthur, L.G. (2012). Effects of level of concentrate supplementation on growth performance of Arsi-Bale and Boer $x$ Arsi-Bale male goats consuming low quality grass hay. Tropical Animal Health Production 44: 1181 -1189.

Stosic, P. (1994). Biological factors influencing the nature of goat skins \& leather. MSc. thesis, University of Leicester.

Teklay, A. (2010). A review on factors affecting the quality of hides and skins. http://www.scribd. com. Accessed 1 December 2014.

Tsegay, T., Mengistu, U., Yoseph, M. (2012). Skin/leather quality of indigenous and crossbred (Dorper $\mathrm{x}$ Indigenous) F1 sheep. Livestock Research for Rural Development. http://www.irrd.org/irrd24/4/tek124056.htm. Accessed 16 June 2104.

Van Soest, P.J., Robertson, J.B. (1985). Analysis of forages and fibrous feeds manual, Department of Animal Science, Cornell Univ. Press, Ithaca, New York.

Venkatachalam, P.S. (1962). Lecture note on leather. APO, CLRI, madras, India.

Virginija, J., Indris, J., Ada, G., Justa, S., Kestutu, B., Virginija, V. (2012). Comparable evaluation of leather waterproofing behavior upon hide quality. Influence of retanning and fat liquoring agents on leather structure and properties. Material Science 18:150-157.

Zeleke, T. (2009). Common defects of sheep and goat skins in Ethiopia and their causes. In: Ethiopia sheep and goat productivity improvement program. Technical bulletin 19: $1-5$. 